\title{
Correction to: Development of a conceptual model and patient- reported outcome measures for assessing symptoms and functioning in patients with heart failure
}

\author{
Olga Moshkovich ${ }^{1}$ (D) Katy Benjamin ${ }^{1,6} \cdot$ Katie Hall $^{1,7} \cdot$ Ryan Murphy $^{1} \cdot$ Robyn von Maltzahn $^{2} \cdot$ Boris Gorsh $^{3}$. \\ Vanja Sikirica $^{3,8} \cdot$ Rajnish Saini ${ }^{4} \cdot$ Dennis Sprecher ${ }^{5,9}$
}

Published online: 17 September 2020

(c) The Author(s) 2020

\section{Correction to: Quality of Life Research https://doi.org/10.1007/s11136-020-02537-y}

The article "Development of a conceptual model and patient-reported outcome measures for assessing symptoms and functioning in patients with heart failure", written by Olga Moshkovich, Katy Benjamin, Katie Hall, Ryan Murphy, Robyn von Maltzahn, Boris Gorsh, Vanja Sikirica, Rajnish Saini and Dennis Sprecher was originally published electronically on the publisher's internet portal on 28 May 2020 without open access. With the author(s)' decision to opt for Open Choice the copyright of the article changed on 15th September to (C) The Author(s) 2020 and the article is forthwith distributed under a Creative Commons Attribution 4.0 International License (https://creativecommons.org/licen

The original article can be found online at https://doi.org/10.1007/ s11136-020-02537-y.

Olga Moshkovich

Olga.Moshkovich@iconplc.com

1 ICON Patient Centered Outcomes, 820 W Diamond Ave, Suite 100, Gaithersburg, MD 20878, USA

2 GSK, Value Evidence and Outcomes, Stockley Park, Uxbridge, Middlesex, UK

3 GSK, Value Evidence and Outcomes, Collegeville, PA, USA

4 GSK, R\&D Future Pipeline Discovery Unit, Collegeville, PA, USA

5 GSK, R\&D Metabolic Pathways and Cardiovascular Unit, Collegeville, PA, USA

6 Present Address: AbbVie, Chicago, IL, USA

7 Present Address: University of Edinburgh, Edinburgh, UK

8 Present Address: PHI Inflammation \& Immunology, Pfizer Inc., Collegeville, PA, USA

9 Present Address: BioView Consultants LLC., Blue Bell, PA, USA ses/by/4.0/), which permits use, sharing, adaptation, distribution and reproduction in any medium or format, as long as you give appropriate credit to the original author(s) and the source, provide a link to the Creative Commons licence, and indicate if changes were made.

The original article has been corrected.

Open Access This article is licensed under a Creative Commons Attribution 4.0 International License, which permits use, sharing, adaptation, distribution and reproduction in any medium or format, as long as you give appropriate credit to the original author(s) and the source, provide a link to the Creative Commons licence, and indicate if changes were made. The images or other third party material in this article are included in the article's Creative Commons licence, unless indicated otherwise in a credit line to the material. If material is not included in the article's Creative Commons licence and your intended use is not permitted by statutory regulation or exceeds the permitted use, you will need to obtain permission directly from the copyright holder. To view a copy of this licence, visit http://creativecommons.org/licenses/by/4.0/.

Publisher's Note Springer Nature remains neutral with regard to jurisdictional claims in published maps and institutional affiliations. 